\title{
Pengembangan model pembelajaran integratif penjasorkes sekolah dasar
}

\author{
Ari Purwantyo ${ }^{1^{*}}$, Tomoliyus ${ }^{2}$ \\ ${ }^{1}$ Prodi IImu Keolahragaan PPs UNY, Universitas Negeri Yogyakarta. \\ ${ }^{2}$ Fakultas IImu Keolahragaan UNY, Universitas Negeri Yogyakarta. \\ ${ }^{*}$ Corresponding Author. Email: purwantyoari@gmail.com
}

\begin{abstract}
Abstrak
Peneilitian ini bertujuan untuk menghasilkan buku panduan model pembelajaran integratif pendidikan jasmani olahraga dan kesehatan SD kelas satu di Kecamatan Depok Sleman melalui permainan semutan. Penelitian pengembangan ini terdiri atas dua tahap, yaitu tahap pra-pengembangan dan tahap pengembangan. Tahap pra-pengembangan terdiri dari kajian literatur, kajian penelitian relevan dan studi lapangan. Tahap pengembangan terdiri penyusunan draf model, validasi ahli, ujicoba terbatas, dan ujicoba luas. Validasi ahli melibatkan 5 orang ahli dengan menggunakan teknik Delphi. Ujicoba skala terbatas dilakukan di SD Deresan. Ujicoba skala luas dilakukan di SD Deresan dan SD Catur Tunggal 7. Instrumen yang digunakan adalah pedoman wawancara, angket dan pedoman pengamatan penilaian. Analisis data pada penelitian ini menggunakan pendekatan deskriptif kualitatif dan kuantitatif. Hasil ujicoba skala terbatas dalam kategori baik dan ujicoba skala luas dalam kategori sangat baik. Model pembelajaran integratif pendidikan jasmani olahraga dan kesehatan efektif untuk meningkatkan afektif (ketertiban dan percaya diri), keterampilan (melempar), pengetahuan (penguasaan pengetahuan permainan dan ketepatan menghitung bola) bagi siswa SD kelas satu.
\end{abstract}

Kata kunci: pengembangan, model, pembelajaran integratif

\section{Developing integrative learning model of penjasorkes of elementary school students}

\begin{abstract}
This study aims to develop an integrative learning model of physical education and health of year-1 of elementary school students in Depok, Sleman District through semutan game. This research development consisted of two phases. They were the pre-development phase and the development phase. Pre-development phase consisted of a literature review, a review of relevant research and field study. The development phase consisted of drafting the model, expert validation, small-scale trials, and large-scale trials. The validation involved 5 experts using the Delphi technique. The small -scale trials were conducted in SD Deresan. Largescale trials were conducted in SD Deresan and SD Catur Tunggal 7. The instruments used were a questionnaire, interview guideline, and guidelines for assessment observations. The data analyses in this study used descriptive qualitative and quantitative approaches. Limited scale test results is in very good category and large scale trials is in the excellent category. The developed integrative learning model of physical education and health is effective for improving affective (orderliness and confidence), skills (throwing), and knowledge (mastery of the game knowledge and accuracy of counting the ball) for year-1 of elementary school students.
\end{abstract}

Keywords: development, models, integrative learning 


\section{PENDAHULUAN}

Indonesia adalah negara yang memiliki sejarah cukup panjang dalam rangka untuk meningkatkan pendidikan warganya. Upaya peningkatan pendidikan itu bermacam-macam, misalnya pemerintah menggelontorkan dana hingga 20\% dari APBN, mewajibkan belajar 9 tahun, membangun fasilitas pendidikan, memberikan penataran-penataran kepada tenaga pendidik, memperbanyak media pembelajaran, mengembangkan kurikulum, dan lain-lain.

Khusus kurikulum, sejak Indonesia merdeka sampai sekarang setidaknya sudah berganti kurikulum sebanyak sembilan kali, secara berurut-urut yaitu: Rencana Pelajaran 1947, Rencana Pelajaran Terurai 1952, Kurikulum 1968, Kurikulum 1975, Kurikulum 1984, Kurikulum 1994 dan Suplemen Kurikulum 1999, Kurikulum 2004, KTSP 2006, dan yang baru adalah Kurikulum 2013 (Loeloek Endah Poerwati, 2013, pp. 4-7)

Kurikulum 2013 menggunakan model pembelajaran integratif (terpadu), merupakan salah satu model implementasi kurikulum yang dianjurkan untuk diaplikasikan pada jenjang pendidikan dasar dan menggunakan metode tematik integratif.

Untuk melaksanakan pendidikan di sekolah dasar salah satunya diperlukan suatu model pembelajaran. Menurut Ahmadi \& Sofan (2014, p. 125) menyatakan bahwa untuk melaksanakan model pembelajaran memerlukan berbagai input, antara lain bahan ajar, metode pembelajaran, evaluasi, sarana prasarana, dan sumber daya lainya (kompetensi guru) serta menciptakan suasana kondusif.

Berdasarkan observasi dan wawancara yang dilakukan peneliti pada empat guru penjasorkes di SD Karangwuni, SD Caturtunggal 3, SD Deresan, dan SD Caturtunggal 7 Kecamatan Depok Sleman menyatakan bahwa hasil pembelajaran pendidikan jasmani olahraga dan kesehatan di SD Kecamatan Depok Sleman belum menggembirakan, terlihat dari masih banyaknya siswa yang nilainya belum tuntas, anak sering tidak tertib misalnya susah diatur, mengganggu teman dan banyak bicara, beberapa faktor lain yang menyebapkan anak nakal adalah karena pengaruh media yang menyiarkan acara-acara kekerasan, kurangnya peran orang tua dalam mendidiak anak, misalnya anak ditinggal kerja seharian. Selain itu ada anak yang tidak aktif dalam mengikuti pembelajaran, suka menyendiri dikarenakan malu dan tidak percaya diri. Selain itu model pembelajaran yang digunakan masih menggunakan metode demonstrasi, pendekatan pembelajaran berpusat pada guru, kurang pahamnya guru terhadap penilaian berbasis kinerja, sarana prasarana kurang menarik, dan guru kurang paham terhadap model pembelajaran integratif.

Berdasarkan permasalahan tersebut perlu dilakukan suatu pemecahan terhadap permasalahan yang dihadapi guru olahraga.

Adapun bentuk pemecahan masalah dengan melakukan penelitian dalam bentuk pengembangan terhadap model pembelajaran yang dapat mendorong pencapaian perkembangan siswa. Salah satu model pembelajaran yang dikembangkan yaitu model pembelajaran integratif yang menggunakan pendekatan pendidikan jasmani olahraga dan kesehatan.

Pengembangan model pembelajaran integratif pendidikan jasmani olahraga dan kesehatan ini diharapkan dapat menghasilkan suatu model pembelajaran yang mendorong siswa selalu senang dan percaya diri dalam melakukan pembelajaran pendidikan jasmani olahraga dan kesehatan.

Manusia dalam kehidupan ini selalu belajar, berlangsung dari sejak lahir sampai mati, sehingga ada kata mutiara yang berbunyi "belajar sepanjang hayat". Belajar bisa dilakukan kapan saja, apa saja, dan dimana saja dalam rangka untuk mempertahankan kehidupanya dan meningkatkan kualitas hidup.

Manusia yang belajar akan berilmu dan manusia yang berilmu akan memiliki kontribusi atau bisa bermanfaat positif bagi kehidupan dirinya, keluarga, masyarakat, bangsa, dan agama, sehingga akan menjadi manusia yang memiliki kedudukan mulia atau terpuji baik secara vertikal maupun horizontal. Melihat betapa pentingnya ilmu, Tuhan selalu menyeru kepada manusia agar selalu minta ilmu kepada-Nya. Tuhan berfirman dalam (QS Thaahaa: 114) "Katakanlah: Ya Tuhanku, tambahkanlah kepadaku ilmu pengetahuan. 
Menurut Supriadie \& Deni Darmawan (2012, p. 27) menyatakan bahwa belajar adalah perubahan tingkah laku. Perubahan itu ditandai oleh terjadinya respons atau reaksi terhadap suatu stimulus (input) yang diolah kemudian diasiosasi (proces/through put) sehingga milik diri dan dapat ditunjuknyatakan sebagai gambaran perubahan tingkah laku hasil belajar (output). Secara skematis digambarkan alur perubahan kegiatan belajar pada gambar 1 sebagai berikut:

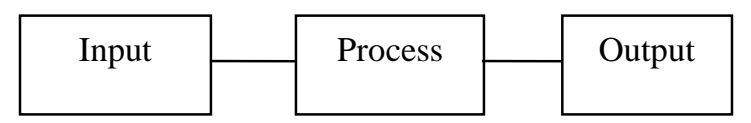

Gambar 1.Alur Perubahan Kegiatan Belajar

Agar diperoleh output yang baik dalam belajar maka perlu strategi pembelajaran. Menurut Saidhihardjo (2004, p. 12) menyatakan bahwa pembelajaran adalah proses interaksi peserta didik dengan pendidik dan sumber belajar pada lingkungan belajar. Berdasarkan strategi yang dilakukan oleh guru secara benar maka tujuan belajar bisa tercapai secara optimal.

Moon (2002, p. 54) menyatakan "the effective is very systematic in the preparation for, and execution, of each lesson". Guru yang efektif sangat sistematis dalam persiapan, dan pelaksanaan dalam setiap pembelajaranya. Ini menunjukan bahwa kegiatan pembelajaran akan efektif apabila direncanakan dan diatur dengan baik.

Selanjutnya Posamentier (2007, p. 47) menyatakan '..., it is universally accepted that a whell-designed lesson plan is the main ingredient of a successful lesson". Ini berarti disamping silabus, guru harus menyiapkan rencana pelaksanaan pembelajaran sebagai bagian utama dari kesuksesan dalam proses pembelajaranya.

Indonesia adalah Negara yang besar yang memiliki masalah kompleks, oleh karena itu untuk mengatasi masalah-masalah itu diperlukan suatu solusi. Salah satu solusi dalam bidang pendidikan adalah, menggunakan pembelajaran integratif untuk jenjang SD Dan sederajat, dengan metode tematik.

Pembelajaran di sekolah dasar dilaksanakan dengan menggunakan pendekatan tematik integratif, khususnya di kelas satu, karena menurut ahli, cara berfikir peserta didik anak usia SD tersebut masih berfikir tentang sesuatu secara utuh/holistik belum pada spesialisasi. Adapun kompetensi peserta didik diharapkan meliputi; sikap, keterampilan, dan pengetahuan yang dikemas oleh guru dalam pembelajaran tematik secara integratif.

Gordon \& Brownw (2011, p. 336) menyatakan bahawa "integrate curriculum means that subject matter is not tought as separate and uniqe topics, such as math, sciene, art, and languge. Instead the are planed components of the total curriculum". Pembelajaran yang terintegrasi merupakan pembelajaran yang dilaksanakan dengan memadukan topik-topik pembelajaran yang diberikan dalam satu kesatuan. Sedangkan Housner (2009, p. 36) menyatakan"internal integration is the process by which the concepts, thinking skills, and social aspects inherent in physical education are specifically taught as an integral part of the curriuculum. external integration is the process by which physical education is integrated with other school subjects"

Adapun penjelasanya adalah, integrasi internal merupakan proses dimana konsep, keterampilan berpikir, dan aspek-aspek sosial yang melekat dalam pendidikan jasmani secara khusus diajarkan sebagai bagian integral dari kurikulum. Misalnya mengintegrasikan antar kompetensi dasar dalam satu mata pelajaran, dalam pendidikan mengajarkan keterampilan motorik, permainan, olahraga, dan kegiatan kebugaran. Integrasi eksternal adalah proses dimana pendidikan jasmani terintegrasi dengan mata pelajaran lain. Misalnya pendidikan jasmani diintegrasikan dengan pelajaran matematika, Pkn, Bahasa Indonesia dan lain-lain.

Adapun mengenai macam modelnya, model pembelajaran integratif terdiri dari sepuluh varian. Berdasarkan pola pengintegrasian tema, Fogarty dalam Trianto (2011, pp. 110-111) menyatakan bahwa terdapat sepuluh model pembelajaran integratif, yaitu: (1) the fragmented model (model tergambarkan), (2) the connected model (model terhubung), (3) 
the nested model (model tersarang), (4) the sequenced model (model terurut), (5) the shared model (model terbagi), (6) the webbed model (model terjaring), (7) the threaded model (model tertali), (8) the integrated model (model terpadu), (9) the immersed model (model terbenam), (10) the networked model (model jejaring).

Pada penelitian model pembelajaran integratif pendidikan jasmani olahraga dan kesehatan sekolah dasar kelas satu di kecamatan Depok Sleman ini menggunakan model pembelajaran integratif jenis model pembelajaran integratif jaring laba-laba (webbed). Trianto (2011, p. 115) menyatakan bahwa pembelajaran integratif model webbed adalah pembelajaran terpadu yang menggunakan pendekatan tematik. Tema tersebut dikembangkan sub-temanya dengan memperhatikan kaitanya dengan bidang-bidang studi. Dari sub-sub tema ini dikembangkan aktivitas belajar yang harus dilakukan siswa. Tema dalam model pembelajaran integratif pendidikan jasmani olahraga dan kesehatan ini ialah kegemaranku dan sub tema gemar berolahraga.

Model pembelajaran integratif yang menggunakan pendekatan pendidikan jasmani olahraga dan kesehatan sekolah dasar kelas satu merupakan model pembelajaran untuk siswa kelas satu sekolah dasar yang dilakukan melalui pendidikan jasmani olahraga dan kesehatan dengan memadukan empat mata pelajaran yaitu Pendidikan Kwarganegaraan, Penjasorkes, Matematika dan Bahasa Indonesia. Pada Model pembelajaran integratif ini dilakukan penilaian terhadap tiga aspek. Aspek sikap, keterampilan, dan pengetahuan.

Mata pelajaran Pkn masuk aspek sikap (ketertiban dan percaya diri), Mata Pelajaran Penjasorkes masuk dalam aspek keterampilan (gerak dasar melempar), mata Pelajaran Matematika dan Bahasa Indonesia masuk aspek pengetahuan (penguasaan pengetahuan permainan dan menghitung jumlah bola). Adapun relevansi matapelajaran Pkn, Penjasorkes, Bahasa Indonesia, dan Matematika terhadap pengembangan model adalah keterhubungan kompetensi dasar yang dipilih untuk disatukan dalam dalam satu sub tema. Kompetensi dari masing-masing pelajaran yang dihubungkan adalah:

1. Pendidikan Kwarganegaraan (4.2 Melaksanakan tata tertib di rumah dan di sekolah)

2. Pendidikan Jasmani Olahraga dan Kesehatan (4.3 Mempraktikkan pola gerak dasar manipulatif sesuai dengan dimensi anggota tubuh yang digunakan, arah, ruang gerak, hubungan dan usaha, dalam berbagai bentuk permainan sederhana dan atau tradisional) .

3. Bahasa Indonesia (3.1 Mengenal teks deskriptif tentang anggota tubuh dan pancaindra, wujud dan sifat benda, serta peristiwa siang dan malam dengan bantuan guru atau teman dalam bahasa Indonesia lisan dan tulis yang dapat diisi dengan kosakata bahasa daerah untuk membantu pemahaman)

4. Matematika (4.3 Mempraktikkan pola gerak dasar manipulatif sesuai dengan dimensi anggota tubuh yang digunakan, arah, ruang gerak, hubungan dan usaha, dalam berbagai bentuk permainan sederhana dan atau tradisional. Untuk lebih jelasnya dapat digambarkan pada gambar 2 berikut: 
Jurnal Pendidikan Jasmani Indonesia, 14 (2), 2018- 42

Ari Purwantyo, Tomoliyus

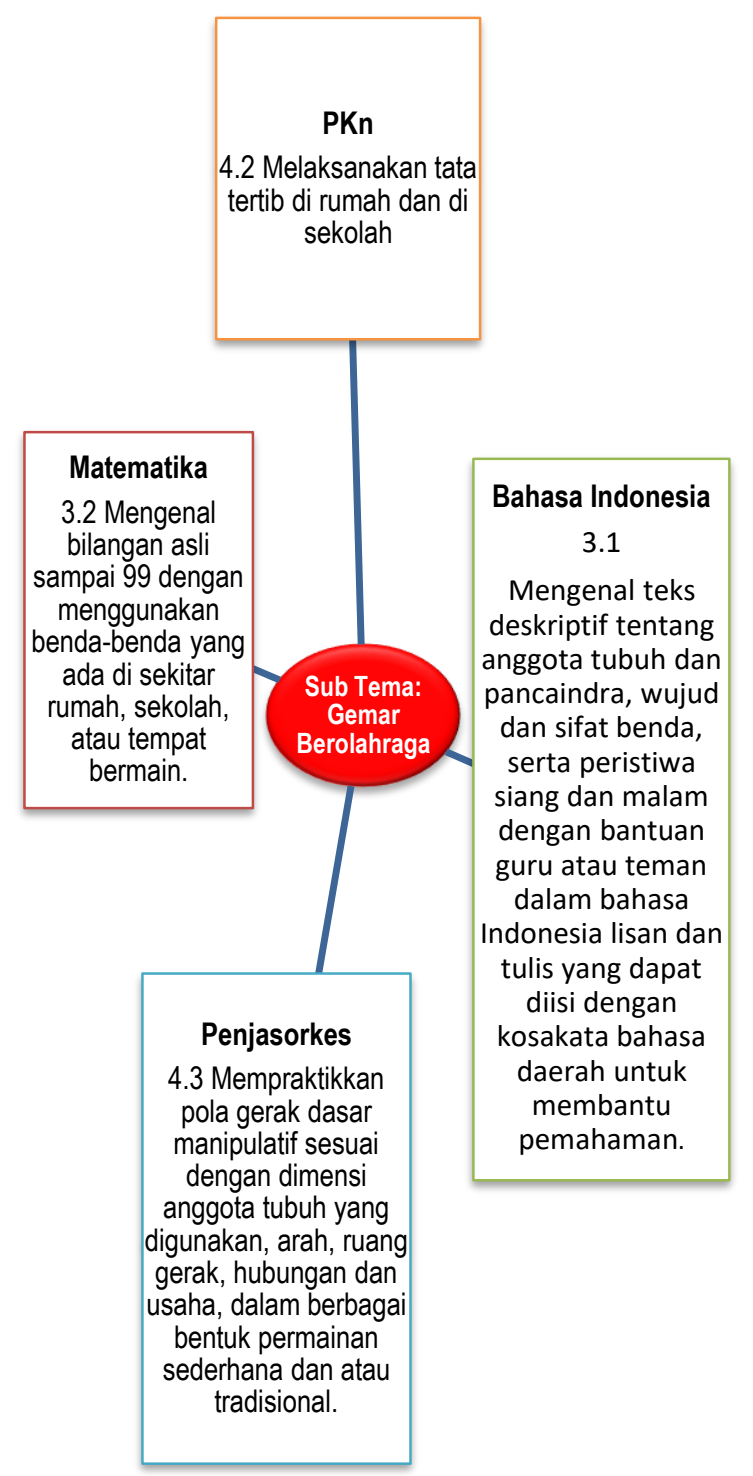

Gambar 2. Model Pembelajaran Integratif

Dari uraian diatas, rumusan masalahnya adalah: (1) Bagaimanakah karakteristik pembelajaran pendidikan jasmani olahraga dan kesehatan SD kelas satu di Kecamatan Depok Sleman. (2) Bagaimanakah proses pelaksanaan model pembelajaran integratif pendidikan jasmani olahraga dan kesehatan SD kelas satu di kecamatan Depok Sleman. (3) Bagaimanakah tingkat efektifitas dari model pembelajaran integratif pendidikan jasmani olahraga SD kelas di Kecamatan Depok Sleman?

\section{METODE PENELITIAN}

\section{Jenis Penelitian}

Penelitian ini dilakukan menggunakan metode penelitian dan pengembangan atau sering disebut (research and development). Penelitian dan pengembangan merupakan metode penelitian untuk menghasilkan produk-produk pendidikan, baik produk yang berupa objek material seperti buku teks, filem pengajar, dan sebagainya. Peneliti memilih model ini karena dipakai untuk mengembangkan dan memvalidasi produk-produk kependidikan, sehingga model pembelajaran integratif pendidikan jasmani olahraga dan kesehatan yang dikembangkan pada penelitian tesis ini sesuai dengan tujuan dari model $R$ \& $D$ yang telah dikembangkan oleh Borg \& Gall.

Dalam penelitian dan pengembangan ini produk yang dihasilkan atau divalidasi berupa buku panduan pembelajaran mengenai proses dan prosedur pelaksanaan model 
pembelajaran atau metode mengorganisir pembelajaran. Dalam penelitian ini produk yang dihasilkan berupa model mengajar untuk siswa sekolah dasar kelas satu dengan melakukan kegiatan pendidikan jasmani olahraga dan kesehatan.

Secara lebih detail mengembangkan prosedur penelitian $R \& D$ ke dalam sepuluh langkah berdasarkan pengalamannnya Borg \& Gall (2007: 580-581). Kesepuluh tahapan tersebut adalah: (1) Penelitian awal dan pengumpulan informasi. (2) Perencanaan.(3) Mengembangan format awal produk. (4) Uji lapangan awal. (5) Revisi produk utama. (6) Uji lapangan utama. (7) Revisi produk secara operasional. (8) Uji lapangan secara operasional. (9) Revisi produk akhir. (10) Diseminasi dan implementasi.

\section{Prosedur Pengembangan}

Berdasarkan 10 langkah penelitian dan pengembangan di atas, dalam penelitian ini pada proses pelaksanaannya melakukan adaptasi yang mengacu pada model pendekatan tersebut. Adapun adaptasi penelitian dan pengembangan ini menjadi 2 tahap yaitu: (1) tahap penelitian pendahuluan yang meliputi studi pustaka serta penelitian yang relevan dan studi lapangan dan (2) tahap pengembangan yang meliputi tahap perencanaan, tahap validasi ahli, dan tahap validasi empirik (uji skala kecil dan skala besar).

\section{Tempat dan Waktu Penelitian}

Uji coba skala kecil dilakukan pada bulan Mei 2014 di SD Deresan. Uji coba skala besar dilakukan pada bulan Juni 2014 di SD Deresan dan SD catur Tunggal 7 Depok Sleman.

\section{Subjek Coba}

Pada tahap validasi ahli subjek coba terdiri dari ahli materi pendidikan penjas, materi pendidikan dasar di SD, ahli bahasa, dan praktisi olahraga. Pada tahap uji coba skala terbatas melibatkan satu kelas dengan 28 orang siswa kelas 1B Sekolah Dasar Deresan dengan satu orang guru olahraga. Pada tahap uji coba skala besar melibatkan 2 kelas dengan 59 orang siswa yaitu siswa kelas satu Sekolah Dasar Catur Tunggal 7 dan siswa kelas 1A SD Deresan dengan dua guru olahraga.

\section{Desain Uji Coba}

Uji coba dilakukan untuk mendapatkan informasi terkait tingkat penggunaan model dan tingkat keefektifan model yang dikembangkan. Sebelum dilakukan uji coba dilapangan (uji coba skala terbatas dan luas), produk penelitian berupa draft modep pembelajaran integratif pendidikan jasmani olahraga dan kesehatan dimintakan validasi terlebih dahulu kepada para pakar yang telah ditunjuk, dalam tahap tersebut selain validasi para pakar juga akan diberikan penilaian terhadap draft model yang telah disusun. Sehingga akan diketahui apakah model yang disusun layak untuk diujicobakan di lapangan.

Uji coba model dilakukan dengan menggunakan model pembelajaran yang telah dikembangkan dalam pembelajaran siswa SD kelas satu. Tujuan dari uji coba model ini untuk mengetahui tingkat kelayakan dan tingkat efektifitas dari model pembelajaran integratif pendidikan jasmani, olahraga, dan kesehatan SD kelas satu di Kecamatan Depok Sleman. Uji coba produk ini dilakukan dengan uji coba terbatas dan uji coba skala luas dari model pembelajaran integratif pendidikan jasmani olahraga dan kesehatan SD kelas satu di Kecamatan Depok Sleman. Model pembelajaran integratif pendidikan jasmani olahraga dan kesehatan SD kelas satu di Kecamatan Depok Sleman dapat dikatakan layak apabila bisa digunakan dalam pembelajaran siswa SD kelas satu. Model ini juga dikatakan efektif apabila dapat meningkatkan perkembangan siswa siswa SD kelas satu.

Pada uji coba model yang telah dikembangkan diujicobakan. Uji coba dilakukan dengan mengimplementasikan model yang dikembangkan dalam pembelajaran sesungguhnya. Guru akan diberikan buku panduan dan diberikan penjelasan mengenai model pembelajaran yang dikembangkan untuk dilaksanakan dalam pembelajaran sesungguhnya. Pada saat proses implementasi model akan dilakukan observasi untuk mengetahui tingkat kegunaan dan kesesuaian model yang mencakup aspek aktivitas atau kegiatan penilaiannya. Setelah dilakukan observasi selanjutnya dilakukan evaluasi dan revisi model. 
Untuk mengetahui tingkat kelayakan model maka digunakan angket untuk menilai keterlaksanaan atau kualitas model. Keterlaksanaan model pembelajaran integratif dinilai oleh praktisi olahraga. Untuk mengetahui kategori deskripsi persentase yang diperoleh, maka dibuat tabel kategori yang disusun dengan perhitungan sebagai berikut: (1) Menentukan angka persentase tertinggi $=(4 / 4) \times 100 \%=100 \%$. (2) Menentukan angka persentase terendah $=(1 / 4) \times 100 \%=25 \%$. (3) Menentukan rentang presentase $=100 \%$ $20 \%=75 \%$. (4) Menentukan interval kelas persentase $=75 \%: 5=15 \%$

Tabel 1. Kategori Hasil Dari Penilaian Praktisi Olahraga

\begin{tabular}{ll}
\hline Persentase & Kategori \\
\hline $25 \%-40 \%$ & Tidak sesuai/baik \\
$41 \%-55 \%$ & Kurang sesuai/baik \\
$56 \%-70 \%$ & Cukup sesuai/baik \\
$71 \%-85 \%$ & Sesuai/baik \\
$86 \%-100 \%$ & Sangat sesuai/baik \\
\hline
\end{tabular}

Adapun desain uji coba menggunakan metode kuasi eksperimen dengan desain single one shot case study. Uji coba dilakukan dengan mengimplementasikan model yang dikembangkan dalam pembelajaran sesungguhnya untuk mengetahui efektifitas model. Jika hasil perhitungan menujukan rata-rata uji coba 2 lebih tinggi dari pada uji coba 1 maka model pembelajaran efektif untuk meningkatkan kemampuan siswa. Berikut digambarkan desain uji coba:

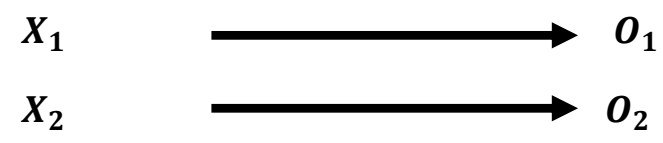

Keterangan:

$\boldsymbol{X}_{\mathbf{1}}, \boldsymbol{X}_{\mathbf{2}}=$ Uji coba ke 1 dan ke 2

$\boldsymbol{O}_{1}, \boldsymbol{O}_{2}=$ Observasi dan Analisis ke 1 dan ke 2

\section{Teknik Pengumpul data}

Pada tahap pra-pengembangan teknik pengumpulan data menggunakan angket dan wawancara mendalam (Indepth Interviews). Pengumpulan data bertujuan untuk memperoleh informasi terkait pelaksanaan pembelajaran yang ada di SD kelas satu meliputi; kompetensi guru, metode pembelajaran, bahan ajar, evaluasi, sarana prasarana, serta hambatan dan solusi dalam pembelajaran penjasorkes.

Pada tahap pengembangan teknik pengumpul data dibagi ke dalam dua kelompok. Kelompok pertama adalah instrumen yang digunakan untuk mengevaluasi model selama proses pengembangan dan ujicoba dan sebagai respondennya adalah guru/praktisi olahraga. Teknik pengumpulan data yang digunakan pada kelompok pertama adalah teknik observasi dan angket.

Kelompok kedua adalah instrumen yang digunakan untuk mengukur tingkat pencapaian kompetensi siswa yang meliputi sikap (afektif), pengetahuan (kognitif), dan keterampilan (psikomotorik) dan sebagai respondennya adalah siswa partisipan. Teknik pengumpulan data yang digunakan pada kelompok kedua menggunakan pedoman pengamatan penilaian.

\section{Teknik Analisis Data}

Data yang diperoleh pada penelitian pendahuluan akan dianalisis dengan menggunakan teknik analisis deskriptif kualitatif. Analisis deskriptif kualitatif digunakan pada angket studi pendahuluan. Teknik analisis deskriptif bertujuan untuk menjelaskan 
karakteristik masing-masing variabel dan mempresentasikan secara obyektif terhadap datadata yang diperoleh.

Pada tahap pengembangan data yang diperoleh akan dianalisis menggunakan beberapa pendekatan yaitu: (1) Pada tahap validasi draf model, data yang diperoleh akan dideskripsikan ke dalam bentuk sajian data dan dianalisis secara kualitatif dan (2) Pada uji skala kecil dan besar hasil uji coba dianalisis menggunakan pendekatan analisis deskriptif dan analisis kuantitatif (statistik). Analisis kuantitatif (statistik) menggunakan analisis statistik uji beda dengan menggunakan statistik non parametrik dengan uji Wilcoxon Signed Ranks Test.

\section{HASIL PENELITIAN DAN PEMBAHASAN}

Hasil penelitian meliputi studi pendahuluan, pengembangan drat model, validasi ahli, uji coba skala terbatas dan ujicoba skala luas, dan uji efektifitas.

Studi Lapangan

Pada tahap studi lapangan dilakukan penyeberan angeket dan wawancara terhadap guru yang mengajar dan siswa sekolah dasar Karangwuni, Sekolah Dasar Cartur Tunggal 3, Sekolah dasar Catur Tunggal 7, dan Sekolah Dasar Deresan untuk mengetahui karakteristik pembelajaran Penjasorkes. Kesemua sekolah dasar itu berada di Kecamatan Depok Sleman Daerah Istimewa Yogyakarta. Berdasarkan hasil angket dan wawancara untuk guru tentang karakteristik pembelajaran penjasorkes SD di Kecamatan Depok Sleman dapat dijelaskan bahwa sarana prasarana yang dimiliki sekolah kurang lengkap, selain itu guru belum mampu menyusun dan melaksanakan model pembelajaran integratif. Hambatan terkait dengan anak didik adalah banyak anak didik yang nakal, tidak tertib dan tidak aktif karena kurang percaya diri sehingga anak tidak mendapat nilai secara tuntas (60\%). Guru juga menyatakan membutuhkan model pembelajaran integratif pendidikan jasmani olahraga dan kesehatan. Selain itu guru juga menyatakan membutuhkan evaluasi model pembelajaran integratif pendidikan jasmanai olahraga dan kesehatan.

\section{Pengembangan drat model}

Berdasarkan analisis kebutuhan, kajian pustaka dan penelitian yang relevan dihasilkan dua aspek pembelajaran yang dikembangkan yaitu desain model pembelajaran dan implementasi model pembelajaran. Dalam pengembangan desain model pembelajaran aspek yang dikembangkan adalah tujuan, pendekatan dan metode pembelajaran, prosedur pelaksanaan dan penilaian hasil belajar.

Dalam pengembangan implementasi pembelajaran diarahkan pada pelaksanaan model pembelajaran. Adapun hasil dari analisis berupa draft model awal model pembelajaran integratif pendidikan jasmani olahraga dan kesehatan sekolah dasar kelas satu adalah model yang diberi nama Kegiatan Permainan Semutan yang dapat meningkatkan aspek sikap, pengetahuan, dan keterampilan.

\section{Validasi}

Tabel 1. Data Validasi Ahli dan Praktisi Olahraga Terhadap Model Pembelajaran

\begin{tabular}{llcccccc}
\hline \multirow{2}{*}{ No } & \multirow{2}{*}{ Aspek yang dinilai } & \multicolumn{7}{c}{ Penilaian ahli } & \multirow{2}{*}{$\Sigma$} \\
\cline { 3 - 6 } & & $\mathbf{1}$ & $\mathbf{2}$ & $\mathbf{3}$ & $\mathbf{4}$ & $\mathbf{5}$ & \\
\hline 1 & Materi & 9 & 9 & 12 & 11 & 9 & 10 \\
2 & Kemanfaatan & 8 & 11 & 12 & 12 & 9 & 10,4 \\
3 & Peralatan & 10 & 12 & 10 & 10 & 9 & 10,2 \\
4 & Bahasa & 5 & 6 & 7 & 8 & 4 & 6 \\
\hline
\end{tabular}

Berdasarkan tabel 1, aspek penilaian materi oleh ke tiga ahli dan dua praktisi olahraga menunjukkan skor 10 artinya isi materi baik. Aspek penilaian kemanfaatan oleh ke tiga ahli dan dua praktisi olahraga menunjukkan skor 10,4 artinya aspek kemanfaatan sangat baik. Aspek penilaian peralatan oleh ke tiga ahli dan dua praktisi olahraga menunjukkan skor 10,2 artinya peralatan yang digunakan sangat baik. Aspek penilaian bahasa oleh ketiga ahli dan dua praktisi olahraga menunjukkan skor artinya bahasa yang digunakan baik. Dapat 
disimpulkan bahwa berdasarkan validasi ahli terhadap model pembelajaran integrative penjasorkes SD kelas satu tergolong baik sehingga model yang dikembangkan layak diujicobakan.

\section{Uji Pelaksanaan Model}

Penilaian pelaksanaan model pembelajaean integratif penjasorkes SD kelas satu dilakukan pada ujicoba skala kecil dan ujicoba skala besar. Penilaian pelaksanaan model pembelajaran pada uji coba skala kecil dilakukan di SD Deresan yaitu sebagai berikut:

Tabel 2. Pelaksanaan model pembelajaran integratif pada uji coba skala kecil

\begin{tabular}{cccc}
\hline No. & Nama Kegiatan & \multicolumn{1}{c}{ Aspek Penilaian } & Penilaian Praktisi \\
\hline & Materi & Baik \\
& & Kemanfaatan & Baik \\
1 & Permainan semutan & Peralatan & Baik \\
& Bahasa & Cukup baik \\
& Keterlaksanaan & Baik \\
& & Menyenangkan & Baik \\
\hline
\end{tabular}

Berdasarkan tabel 2, hasil penilaian pelaksanaan model pembelajaran integratif Penjasorkes SD kelas satu didapatkan data yaitu: (1) Nilai pada aspek materi $9(75 \%)$ artinya baik. (2) Nilai pada aspek kemanfaatan 9 (75\%) artinya baik. (3) Nilai pada aspek peralatan $9(75 \%)$ artinya baik. (4) Nilai pada aspek bahasa $5(62 \%)$ artinya cukup baik. (5) Nilai pada aspek keterlaksanaan $10(83 \%)$ artinya baik. (6) Nilai pada aspek menyenangkan 6 (75) artinya baik. Jumlah nilai total aspek 48 (75\%) artinya baik. Dari hasil penilaian pelaksanakan model dapat disimpulkan bahwa hasil pelaksanaan kegiatan pembelajaran menggunakan model pembelajaran integratif Penjasorkes SD kelas satu pada uji coba skala kecil dapat dilaksanakan dengan baik.

Penilaian pelaksanaan model pembelajaran pada ujicoba skala besar dilakukan di SD Deresan dan SD catur Tunggal 7 yaitu sebagai berikut.

Tabel 3. Pelaksanaan model pembelajaran integratif pada uji coba skala besar

\begin{tabular}{cccc}
\hline No & Nama Kegiatan & \multicolumn{1}{c}{ Aspek Penilaian } & Penilaian Praktisi \\
\hline \multirow{4}{*}{1} & Materi & Sangat baik \\
& \multirow{4}{*}{ Permainan semutan } & Kemanfaatan & Sangat baik \\
& Peralatan & Sangat baik \\
& & Bahasa & Sangat baik \\
& & Keterlaksanaan & Sangat baik \\
& Menyenangkan & Sangat baik \\
\hline
\end{tabular}

Berdasarkan tabel 2, hasil penilaian pelaksanaan model pembelajaran integratif Penjasorkes SD kelas satu didapatkan data yaitu: (1) Nilai pada aspek materi $22(91 \%)$ artinya sangat baik. (2) Nilai pada aspek kemanfaatan 22 (91\%) artinya sangat baik. (3) Nilai pada aspek peralatan $24(100 \%)$ artinya sangat baik. (4) Nilai pada aspek bahasa $15(94 \%)$ artinya sangat baik. (5) Nilai pada aspek keterlaksanaan $23(95 \%)$ artinya sangat baik. (6) Nilai pada aspek menyenangkan 14 (88) artinya baik. Jumlah nilai total aspek 120 (94\%) artinya sangat baik. Dari hasil penilaian pelaksanakan model dapat disimpulkan bahwa hasil pelaksanaan kegiatan pembelajaran menggunakan model pembelajaran integratif Penjasorkes SD kelas satu pada uji coba skala besar dapat dilaksanakan dengan sangat baik.

\section{Uji Efektifitas Model}

Uji efektivitas terhadap model pembelajaran integratif penjasorkes SD kelas satu terdiri dari dua tahap yaitu: tahap uji coba skala kecil dilakukan di SD Deresan. Pada tahap uji coba skala besar dilakukan di dua tempat yaitu SD Deresan dan SD Catur Tunggal 7, uji coba masing-masing dilakukan selama dua kali pertemuan. Hasil uji coba efektivitas model pembelajaran pada skala kecil sebagai berikut. 
Tabel 4. Data Hasil Uji Efektivitas Model Pembelajaran Integratif Pada Uji coba Skala Kecil

\begin{tabular}{cccccc}
\hline & \multicolumn{5}{c}{ Aspek } \\
\cline { 2 - 6 } Uji coba 1 dan 2 & \multicolumn{2}{c}{ Sikap } & Keterampilan & \multicolumn{2}{c}{ Pengetahuan } \\
\cline { 2 - 6 } & Ketertiban & $\begin{array}{c}\text { Percaya } \\
\text { Diri }\end{array}$ & $\begin{array}{c}\text { Gerak dasar } \\
\text { melempar }\end{array}$ & $\begin{array}{c}\text { Penguasaan } \\
\text { pengetahuan } \\
\text { permainan }\end{array}$ & $\begin{array}{c}\text { Ketepatan } \\
\text { menghitung } \\
\text { jumlah bola }\end{array}$ \\
\hline Mean uji coba 1 & 1,36 & 1,32 & 1,29 & 1,34 & 1,36 \\
Mean uji coba 2 & 1,79 & 1,96 & 1,64 & 2,29 & 2,18 \\
Z & $-2,972^{\underline{a}}$ & $-3,448^{\underline{a}}$ & $-3,162^{\mathrm{a}}$ & $-4,012^{\mathrm{a}}$ & $-3.508^{\mathrm{a}}$ \\
Asymp. Sig. (2-Tailed &, 003 &, 001 &, 002 &, 000 &, 000 \\
\hline
\end{tabular}

Berdasarkan hasil perhitungan pada table 4, dapat dijelaskan bahwa pembelajaran integratif pendidikan jasmani olahraga dan kesehatan siswa sekolah dasar kelas satu dapat meningkatkan kemampuan sikap, keterampilan dan pengetahuan siswa. Pada uji coba skala terbatas mean ujicoba 2 lebih tinggi daripada mean uji coba 1. Pada aspek sikap, ketertiban mean uji coba $2(1,79)$ lebih tinggi dari pada mean uji coba $1(1,36)$, percaya diri mean uji coba $2(1,96)$ lebih tinggi daripada mean uji coba $1(1,32)$. Pada aspek keterampilan gerak dasar melempar mean uji coba $2(1,64)$ lebih tinggi daripada mean uji coba $1(1,29)$. Pada aspek pengetahuan, penguasaan pengetahuan mean uji coba $2(2,29)$ lebih tinggi dari mean uji coba $1(1,36)$, ketepatan menghitung jumlah bola mean ujicoba $2(2,18)$ lebih besar dari mean uji coba $1(1,36)$.Pada aspek pengetahuan, penguasaan pengetahuan mean uji coba 2 $(2,29)$ lebih tinggi dari mean uji coba $1(1,36)$, ketepatan menghitung jumlah bola mean uji coba $2(2,18)$ lebih besar dari mean uji coba $1(1,36)$.

Jadi dapat disimpulkan bahwa model pembelajaran integratif pendidikan jasmani olahraga dan kesehatan SD kelas satu efektif untuk meningkatkan kemampuan sikap (ketertiban dan percaya diri), keterampilan (melempar), dan pengetahuan (penguasaan pengetahuan permainan dan ketepatan menghitung jumlah bola) karena nilai rata-rata pada uji coba 2 lebih tinggi dari pada nilai rata-rata pada uji coba 1.

Hasil uji coba efektivitas model pembelajaran pada skala besar di dua tempat yatu SD Deresan dan SD Catur Tunggal 7 sebagai berikut.

Tabel 5. Data Hasil Uji Efektivitas Model Pembelajaran Integratif

\begin{tabular}{cccccc}
\hline \multirow{2}{*}{$\begin{array}{c}\text { Pada Uji coba } \\
\text { Skala }\end{array}$} & \multicolumn{5}{c}{ Aspek } \\
\cline { 2 - 6 } $\begin{array}{c}\text { BesarUjicoba 1 } \\
\text { dan 2 }\end{array}$ & Ketertiban & $\begin{array}{c}\text { Percaya } \\
\text { diri }\end{array}$ & $\begin{array}{c}\text { Gerak dasar } \\
\text { melmpar }\end{array}$ & $\begin{array}{c}\text { Penguasaan } \\
\text { pengetahuan } \\
\text { permainan }\end{array}$ & $\begin{array}{c}\text { Ketepatan } \\
\text { menghitung } \\
\text { jumlah bola }\end{array}$ \\
\hline Mean uji coba 1 & 1,86 & 1,83 & 1,41 & 2,19 & 2,05 \\
Mean uji coba 2 & 2,81 & 2,83 & 1,92 & 3,76 & 3,78 \\
Z & $-5,579^{\underline{a}}$ & $-5,820^{\underline{a}}$ & $-5,303^{\underline{a}}$ & $-6,265^{\underline{a}}$ & $-6,302^{\underline{a}}$ \\
$\begin{array}{c}\text { Asymp. Sig.(2- } \\
\text { Tailed }\end{array}$ &, 000 &, 000 &, 000 &, 000 &, 000 \\
\hline
\end{tabular}

Berdasarkan hasil perhitungan pada table 5 , dapat dijelaskan bahwa pembelajaran integratif pendidikan jasmani olahraga dan kesehatan siswa sekolah dasar kelas satu berdasarkan dapat meningkatkan kemampuan sikap, keterampilan, dan pengetahuan siswa. Pada uji coba skala luas mean ujicoba 2 lebih tinggi daripada mean uji coba 1. Pada aspek sikap, ketertiban mean uji coba $2(2,81)$ lebih tinggi dari pada mean uji coba $1(1,86)$, percaya diri mean ujicoba $2(2,83)$ lebih tinggi dari pada mean ujicoba $1(1,83)$. Pada aspek keterampilan gerak dasar melempar, mean uji coba $2(1,92)$ lebih tinggi dari pada mean uji coba $1(1,41)$. Pada aspek pengetahuan, penguasaan pengetahuan permainan mean uji 
coba $2(3,76)$ lebih tinggi dari pada mean uji coba $1(2,19)$, ketetapan menghitung jumlah bola mean uji coba $2(3,78)$ lebih tinggi dari pada mean uji coba $1(2,05)$.

Jadi dapat disimpulkan bahwa model pembelajaran integratif pendidikan jasmani olahraga dan kesehatan SD kelas satu efektif untuk meningkatkan kemampuan sikap (ketertiban dan percaya diri), keterampilan (melempar), dan pengetahuan (penguasaan pengetahuan permainan dan ketepatan menghitung jumlah bola) karena nilai rata-rata pada uji coba 2 lebih tinggi dari pada nilai rata-rata pada uji coba 1.

\section{SIMPULAN DAN SARAN}

\section{Simpulan}

Berdasarkan hasil penelitian dan pembahasan dapat disimpulkan bahwa karakteristik pembelajaran penjasorkes SD di Kecamatan Depok Sleman masih terdapat beberapa kendala karena sarana prasarana yang dimiliki sekolah kurang lengkap, selain itu guru belum mampu menyusun dan melaksanakan model pembelajaran integratif. Hambatan terkait dengan anak didik adalah banyak anak didik yang nakal, tidak tertib dan tidak aktif karena kurang percaya diri sehingga anak tidak mendapat nilai secara tuntas (60\%). Guru juga menyatakan membutuhkan model pembelajaran integratif pendidikan jasmani olahraga dan kesehatan. Selain itu guru juga menyatakan membutuhkan evaluasi model pembelajaran integratif pendidikan jasmanai olahraga dan kesehatan.

Model pembelajaran integratif pendidikan jasmani olahraga dan kesehatan SD kelas satu di Kecamatan Depok Sleman yang dikembangkan, berdasarkan hasil validasi dihasilkan model integratif pendidikan jasmani olahraga SD kelas satu dalam kategori baik. Selanjutnya berdasarkan pada hasil diimplementasikan model yang dilakukan melalui dua tahapan yaitu uji coba skala terbatas dua kali dan uji coba skala luas dua kali. Berdasarkan hasil implementasi uji coba model pembelajaran integratif pendidikan jasmani olahraga dan kesehatan pada skala terbatas pelaksanaannya tergolong baik. Pada uji coba luas pelaksanaanya tergolong sangat baik.

Berdasarkan perhitungan pada perbedaan pemerolehan hasil belajar pertemuan pertama dengan pertemuan kedua menunjukan bahwa nilai rata-rata pemerolehan hasil belajar pertemuan kedua lebih tinggi dari nilai rata-rata pemerolehan hasil belajar pertemuan pertama. Model pembelajaran integratif pendidikan jasmani olahraga untuk sekolah dasar kelas satu efektif untuk meningkatkan sikap, keterampilan, dan pengetahuan. Efektifitas ini dapat dilihat dari perbedaan pemerolehan hasil berlajar pada pertemuan pertama dengan pertemuan kedua.

\section{Saran}

Guna mendukung keberhasilan guru dalam menggunakan model pembelajaran integratif pendidikan jasmani olahraga dan kesehatan SD kelas satu, sebaiknya guru penjasorkes segera: (1) memperbaiki kelemahan yang muncul dalam pelaksanaannya agar pelaksanaanya dapat berjalan secara optimal, meskipun hal tersebut berarti menambah kesibukan guru dalam menyiapkan bahan-bahan pembelajaran, (2) lebih bersungguhsungguh dalam melaksanakan pembelajaran sesuai dengan prosedur yang telah dibuat sehingga melakukan asesmen proses dan hasil belajar mengacu penilaian yang telah dibuat.

Bagi peneliti berikutnya sebaiknya: (1) melakukan penelitian lebih lanjut melalui penelitian pra eksperimen dengan melibatkan guru SD untuk mengetahui efek nyata dari produk permainan ini, (2) melakukan pengembangan produk lebih lanjut, selain berupa buku panduan permainan, produk penelitian dibuat dalam bentuk CD pembelajaran, (3) melakukan penelitian yang melibatkan subjek coba lebih besar dan cakupan tempat uji coba yang lebih luas sehingga dapat diterapkan di wilayah lain.

\section{DAFTAR PUSTAKA}

Borg, W.R., \& Gall, M.D. (2007). Education reaserch. $7^{\text {th }}$ ed.) New York: Longman Inc.

Gordon, A.M \& Browne, K.W. (2011). Beginings and beyond: Foundation in early cilhood education, ( $8^{\text {th }}$ ed.). Brlmont: Wadsworth. 
Ahmadi, L. K. \& Sofan, A. (2014). Pengembangan \& model pembelajaran tematik integratif. Jakarta: Prestasi Pustaka.

Loeloek, E., P \& Sofan Amri. (2013). Panduan memahami kurikulum 2013. Jakarta: Prestasi Pustaka.

Housner L. D. (2009). Integrated physical education: a guide for the elementary classroom teacher. West Virginia University: Fitnes Information Technology.

Moon, B., Mayes, A.S., \& Hutchinson, S. (Ed). (2002). Teaching, learning and the curriculum in secondary school. New York: Routlede Falmer.

Posamentier, A.S., \& Krulik, S. (2007). Exemplary practices for secondary math Teachers. Alexandria: ASCD.

Supriadie \& Dermawan, Deni (2012). Komunikasi pembelajaran. Bandung: PT Remaja Rosdakarya Offset.

Saidihardjo. (2004). Pengembangan kurikulum ilmu pengetahuan social (IPS). Yogyakarta: Universitas Negeri Yogyakarta.

Trianto. (2011). Desain pengembangan pembelajaran tematik: Bagi anak usia dini TK/Ra \& anak usia kelas awal SD/MI. Jakarta: Kencana. 